\title{
Drug Effect in Acute Leukemia
}

\author{
Beatrice C. Lampkin, Takeshi Nagao, and Alvin M. Mauer \\ From the Department of Pediatrics, University of Cincinnati, The Children's \\ Hospital, and The Children's Hospital Research Foundation, \\ Cincinnati, Ohio 45229
}

A B STRACT The in vivo therapeutic effect of vincristine, cytosine arabinoside, and corticosteroids on leukemic blast cells in the bone marrow was evaluated. 24 studies were done in 21 children with acute leukemia. 19 children had acute lymphoblastic leukemia, and two children had acute myeloblastic leukemia. Direct cytotoxicity or lysis of blast cells after drug administration was looked for by serial measurements of the volume of marrow buffy coat. Changes in proliferative capacity were evaluated by serial measurements of number of cells in mitosis and the per cent of cells in deoxyribonucleic acid (DNA) synthesis, as indicated by tritiated thymidine incorporation. Corticosteroid administration caused lysis of leukemic blast cells. Each drug affected the proliferative capacity of the leukemic cells by an action at a different part of the mitotic cycle. Corticosteroids suppressed the entry of cells into DNA synthesis. Vincristine arrested cells in mitosis. Cytosine arabinoside inhibited DNA synthesis. After the inhibitory effect of cytosine arabinoside, an increased number of cells began to synthesize DNA, a phenomenon indicating that partial synchronization of the mitotic cycle had been achieved in the leukemic cell population. The action of these drugs at different parts of the mitotic cycle might be important in designing treatment regimens where in two or more of these drugs are used.

\section{INTRODUCTION}

Knowledge of the manner by which chemotherapeutic agents induce a remission in acute leukemia is desirable for the proper use of these drugs. The following study was done to evaluate the in vivo effect of three types of chemotherapeutic agents on leukemic cells in the bone

This work was presented in preliminary form at the meeting of the American Pediatric Society, May 1968, and the XIIth Congress of the International Society of Hematology, September 1968.

Dr. Lampkin was an Advanced Clinical Fellow of the American Cancer Society, Inc.

Received for publication 8 January 1969. marrow. The agents studied were vincristine, cytosine arabinoside, and corticosteroids. Direct cytotoxicity or cell lysis was measured by changes in the volume of marrow buffy coat. Effects on proliferative capacity were determined by serial measurements of cells in mitosis and the per cent of cells in DNA synthesis as indicated by tritiated thymidine incorporation. From the results of the study, each of the agents interferes with cell proliferation at a different phase of the mitotic cycle. In addition, corticosteroids have a direct lytic effect on some leukemic cell populations.

\section{METHODS}

24 studies were done in 21 children with acute leukemia. The classification of the type of leukemia was done by morphological and histochemical criteria $(1,2) .19$ children had acute lymphoblastic leukemia and two had acute myeloblastic leukemia. The patients were from 2 to $13 \mathrm{yr}$ of age. All studies were done with informed consent of the parents and in accordance with standards for clinical research in humans established at our institution.

In those patients who were not studied at time of diagnosis, previous chemotherapy had been stopped at least $24 \mathrm{hr}$ before drug evaluation. The bone marrow samples were found to be $89-100 \%$ replaced by leukemic cells at the time of the study except in the case of patient No. 6 shown in Table III. The drug, hydrocortisone, was also evaluated in one patient with idiopathic thrombocytopenic purpura, one patient with congenital hypoplastic anemia, and four normal dogs.

In each study, a bone marrow sample was obtained before drug administration and serially thereafter after the administration of vincristine, corticosteroids, or cytosine arabinoside. The marrow samples were aspirated from the anterior or posterior iliac crests or vertebral spinous processes.

The mitotic index was determined by a modification of the method of Japa (3). Approximately $0.25 \mathrm{ml}$ of bone marrow was aspirated into a plastic syringe and discharged into a watch glass where the sample was immediately covered with acetocarmine solution. After $10 \mathrm{~min}$, marrow particles were transferred to glass slides and covered with cover slips which were then sealed at the edges with silicone grease. The number of mitotic figures per $1000 \mathrm{nu}-$ cleated cells was counted from 10 cover slip preparations for each time period and recorded as the total number of cells in mitosis per 10,000 nucleated cells.

1124 The Journal of Clinical Investigation Volume 481969 
After redirecting the bone marrow needle, approximately $1.5 \mathrm{ml}$ of marrow was drawn into a syringe wetted with a $1: 5$ dilution of heparin $(1000 \mathrm{U} / \mathrm{ml})$ in saline. A $1 \mathrm{ml}$ aliquot was then incubated with $1 \mu \mathrm{c}$ of tritiated thymidine (specific activity $1.9 \mathrm{c} / \mathrm{mmole}$ ) for $50 \mathrm{~min}$ at $37^{\circ} \mathrm{C}$ with constant shaking. The sample was then transferred to a disposable sedimentation tube and centrifuged at $1200 \mathrm{~g}$ for 10 min.

The marrow buffy coat of the sample was measured and recorded as a per cent of the total volume (4). The buffy coat was then carefully removed with a pasteur pipette, transferred to a watch glass, and mixed well with the same pipette. Cover slip smears of the buffy coat were made and radioautographs prepared with Kodak AR 10 stripping film. The radioautographs from each study were prepared at the same time and stored at $4^{\circ} \mathrm{C}$. After an exposure period of from 7 to 13 days the films were developed and the slides stained with Wright's stain.

From 2300 to 3500 leukemic cells from six cover slip preparations were counted for each time period and the per cent of labeled blasts recorded. In some studies the number of grains over each labeled nucleus were counted and the mean grain count for the labeled cell population determined. In the nonleukemic marrow samples, 500 myeloid precursors (myeloblasts, promyelocytes, and myelocytes) were counted for each time period and the per cent of labeled precursor cells recorded.

The changes in the per cent of cells labeled with tritiated thymidine and the number of mitotic figures after therapy were compared to control values obtained before drug administration. The results were subjected to the $Z$ test (5). An absolute $Z$ value greater than 1.96 is significant at the $5 \%$ level, and an absolute $Z$ value greater than 2.58 is significant at the $1 \%$ level.

\section{RESULTS}

\section{Vincristine}

Seven studies were done in seven children with acute lymphoblastic leukemia after a single injection of vincristine in a dose of $0.075 \mathrm{mg} / \mathrm{kg}$ (Table I). Four of these patients were studied at time of diagnosis. Two were studied after relapse while taking 6-mercaptopu- rine, and one after relapse during methotrexate administration. None of these patients had previously received vincristine.

A summary of the effects of vincristine in six of the patients is shown in Table I. The results were similar in these patients with a maximal number of mitotic figures occurring 12-24 hr after the injection. A minimal labeling index was found $24-48 \mathrm{hr}$ after the injection. The marrow buffy coat was approximately $50 \%$ of the control level by the 24 or $48 \mathrm{hr}$ sample. In the remaining patient both the number of mitotic figures and the labeling index were increased over control values 24 and 48 $\mathrm{hr}$ after the drug, and there was no change in the marrow buffy coat.

A representative example (patient No. 6 in Table I) of the time course of the effect of vincristine on the labeling index and number of mitotic figures is shown in Fig. 1. $24 \mathrm{hr}$ after vincristine there was a striking increase in the number of mitotic figures. No change in labeling index was seen until the $48 \mathrm{hr}$ sample.

\section{Cytosine arabinoside}

Four studies were done in three children with acute lymphoblastic leukemia after a single injection of cytosine arabinoside in a dose of $5 \mathrm{mg} / \mathrm{kg}$ body weight. All of these patients had been previously treated with prednisone, vincristine, methotrexate, 6-mercaptopurine, and cyclophosphamide and were resistant to these drugs. At the time of study two patients had been receiving 6-mercaptopurine and another cyclophosphamide. The fourth study was done at the time of relapse 1 month after a remission had been induced with cytosine arabinoside.

The time course for changes in the labeling index and the number of mitotic figures with cytosine arabinoside administration are shown in Figs. 2 and 3. In both figures the two studies done in the same patient are

TABLE I

Vincristine Effect

\begin{tabular}{|c|c|c|c|c|c|c|c|c|c|}
\hline \multirow[b]{2}{*}{$\begin{array}{l}\text { Patient } \\
\text { No. }\end{array}$} & \multirow[b]{2}{*}{ Time studied } & \multicolumn{4}{|c|}{ Mitotic figures per 10,000 cells } & \multicolumn{4}{|c|}{ Labeling index (per cent)* } \\
\hline & & Control & $\begin{array}{l}\text { Max- } \\
\text { imum }\end{array}$ & $\begin{array}{c}\text { Hours } \\
\text { after } \\
\text { injec- } \\
\text { tion }\end{array}$ & {$[Z] \ddagger$} & Control & $\begin{array}{l}\text { Min- } \\
\text { imum }\end{array}$ & $\begin{array}{l}\text { Hours } \\
\text { after } \\
\text { injec- } \\
\text { tion }\end{array}$ & {$[Z]^{*}$} \\
\hline 1 & Relapse, 6-mercaptopurine & 134 & 524 & 24 & 15.3 & 29.0 & 20.6 & 48 & 6.5 \\
\hline 2 & Diagnosis & 59 & 249 & 12 & 10.8 & 4.6 & 3.0 & 24 & 3.2 \\
\hline 3 & Diagnosis & 48 & 578 & 24 & 18.6 & 9.1 & 3.1 & 48 & 9.5 \\
\hline 4 & Relapse, 6-mercaptopurine & 23 & 185 & 12 & 11.2 & 3.4 & 1.6 & 48 & 4.5 \\
\hline 5 & Diagnosis & 108 & 1428 & 24 & 33.4 & 20.4 & 6.3 & 48 & 14.6 \\
\hline 6 & Relapse, methotrexate & 128 & 1074 & 24 & 24.4 & 23.9 & 5.0 & 48 & 19.2 \\
\hline
\end{tabular}

$*=3000$ lymphoblasts counted per time period.

$\ddagger[Z]=$ Absolute $Z$ value. 


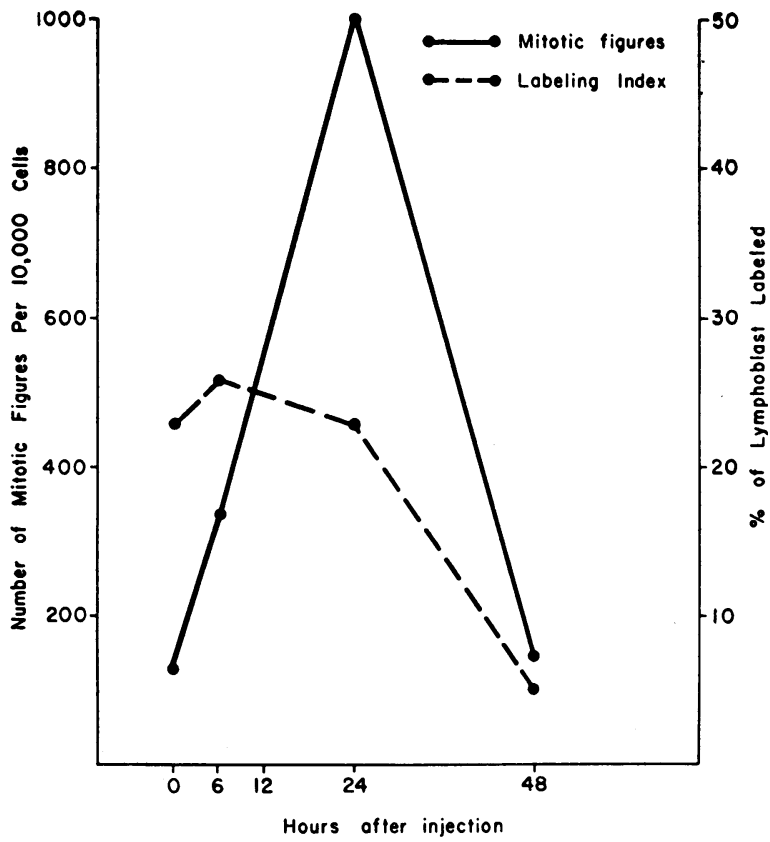

FIGURE 1 Representative example of vincristine effect. Acute lymphoblastic leukemia.

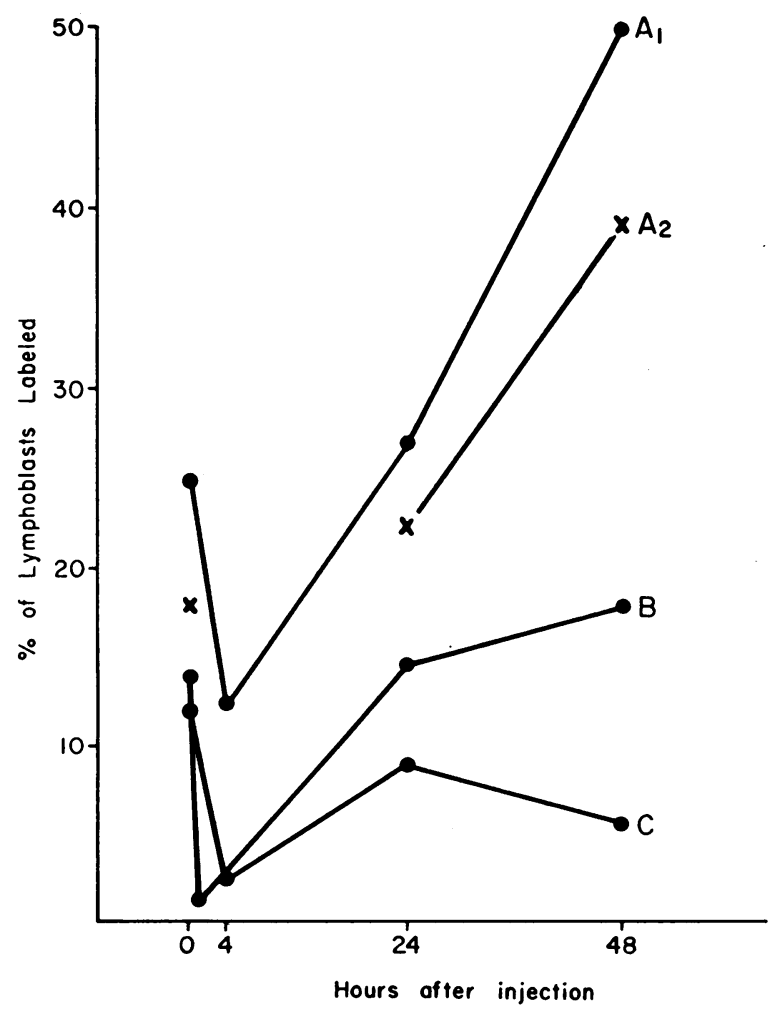

Figure 2 Effect of cytosine arabinoside on labeling index. Acute lymphoblastic leukemia. designated $A_{1}$ and $A_{2}$. In the second study no marrow sample could be obtained at $4 \mathrm{hr}$.

The labeling index as shown in Fig. 2 was markedly decreased by $1-4 \mathrm{hr}$. At that time the quantity of label per cell as indicated by grain count was also markedly reduced (Table II). $24 \mathrm{hr}$ after injection the labeling index had returned or almost returned to pretreatment levels. In patient $A$ there was a striking increase in per cent of labeled blast cells over pretreatment levels $48 \mathrm{hr}$ after injection in both studies. In patient $\mathrm{B}$ a significant ([Z] 3.8) but less striking increase in labeling index over pretreatment levels was seen at that time. By $48 \mathrm{hr}$ the quantity of label per blast cell had almost returned to pretreatment levels (Table II).

In each patient there was a marked decrease in the number of mitotic figures by $24 \mathrm{hr}$ after drug administration. In the two marrow specimens obtained at $4 \mathrm{hr}$ there also was a marked decrease observed. In the one patient in whom a marrow sample was obtained at $1 \mathrm{hr}$, however, no change in number of mitotic figures had yet occurred. By $48 \mathrm{hr}$ in each patient the number of mitotic figures had almost returned to pretreatment levels or were greater than these values. In none of the studies was a change in marrow buffy coat observed.

\section{Corticosteroids: prednisone}

Four studies were done to evaluate the effect of a 1 wk course of prednisone in a dose of $2.2 \mathrm{mg} / \mathrm{kg}$ body

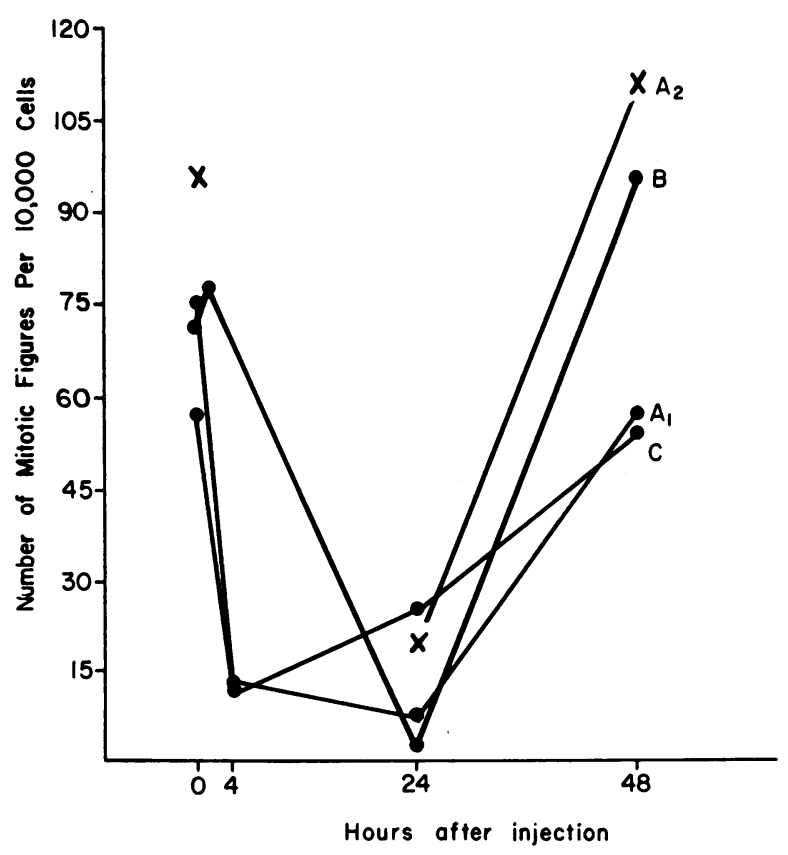

FIGURE 3 Effect of cytosine arabinoside on number of mitotic figures. Acute lymphoblastic leukemia. 
TABLE II

Mean Grain Counts after Cytosine Arabinoside and Hydrocortisone*

\begin{tabular}{cccccc}
\hline & \multicolumn{2}{c}{$\begin{array}{c}\text { After cytosine } \\
\text { arabinoside }\end{array}$} & & \multicolumn{2}{c}{ After hydrocortisone } \\
\cline { 2 - 3 } $\begin{array}{c}\text { Hours after } \\
\text { injection }\end{array}$ & $\begin{array}{c}\text { Patient } \\
\text { A1 }\end{array}$ & $\begin{array}{c}\text { Patient } \\
\text { B }\end{array}$ & & $\begin{array}{c}\text { Patient } \\
\text { No. 2 }\end{array}$ & $\begin{array}{c}\text { Patient } \\
\text { No. } 5\end{array}$ \\
\hline 0 & 78 & 49 & & 18.8 & 65.0 \\
1 & 33 & 18 & & & \\
4 & 36 & 39 & & 25.1 & 63.4 \\
24 & 65 & 41 & & \\
48 & & & & & \\
\hline
\end{tabular}

* Determined by counting 100 labeled cells.

weight. Three patients were studied at the time of diagnosis and without previous therapy. In the fourth patient the prednisone was begun $48 \mathrm{hr}$ after the injection of hydrocortisone in a dose of $11 \mathrm{mg} / \mathrm{kg}$ body weight. In two patients the prednisone was continued for $4 \mathrm{wk}$ at which time a complete bone marrow remission was evident. In the remaining two patients 6-mercaptopurine was added to the regimen after the study period. Before treatment the marrow samples were hypercellular on direct smear. After $1 \mathrm{wk}$ of therapy all samples were markedly hypocellular on direct smear. In one patient marrow buffy coat was measured and found to be $15 \%$ before but only a trace after therapy. As shown in Fig. 4, the labeling index of the leukemic blast cells decreased markedly after $1 \mathrm{wk}$ of prednisone.

\section{Corticosteroids: hydrocortisone}

Acute lymphoblastic leukemia. Seven studies were done in seven children with acute lymphoblastic leukemia to evaluate the effect of a single injection of hy-

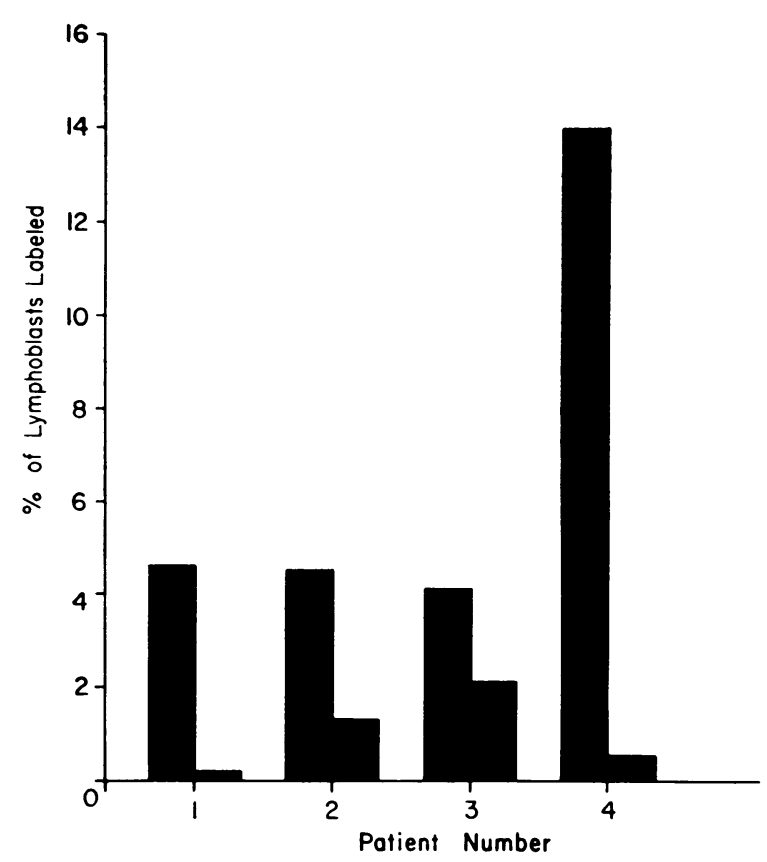

Figure 4 Effect of prednisone on labeling index. Acute lymphoblastic leukemia.

drocortisone in a dose of $11 \mathrm{mg} / \mathrm{kg}$ body weight. Two of these patients (patient Nos. 2 and 7 in Table III) were studied at the time of diagnosis. The remaining five patients were studied after relapse while taking 6-mercaptopurine. These patients had previously achieved a remission with combined prednisone and 6-mercaptopurine. One of these patients (patient No. 1 in Table III) had been in the prednisone study group.

As in the prednisone-treated patients, there was a significant decrease in labeling index after the hydro-

TABLE III

Hydrocortisone Effect

\begin{tabular}{|c|c|c|c|c|c|c|c|c|c|c|}
\hline \multirow[b]{2}{*}{$\begin{array}{l}\text { Patient } \\
\text { No. }\end{array}$} & \multirow[b]{2}{*}{ Time studied } & \multicolumn{5}{|c|}{ Labeling index } & \multicolumn{4}{|c|}{ Mitotic figures per 10,000 cells } \\
\hline & & Control & $\begin{array}{l}\text { Min- } \\
\text { imum }\end{array}$ & $\begin{array}{l}\text { Hours } \\
\text { after } \\
\text { injec- } \\
\text { tion }\end{array}$ & $\begin{array}{c}\text { No. } \\
\text { cells* }\end{array}$ & {$[Z]+$} & Control & $\begin{array}{l}\text { Min- } \\
\text { imum }\end{array}$ & $\begin{array}{l}\text { Hours } \\
\text { after } \\
\text { injec- } \\
\text { tion }\end{array}$ & {$[Z]_{+}^{+}$} \\
\hline 1 & Relapse, 6-mercaptopurine & 18.8 & 8.7 & 24 & 3000 & 10.49 & 168 & 124 & 48 & 2.57 \\
\hline 2 & Diagnosis & 7.9 & 2.5 & 24 & 2300 & 8.09 & $\begin{array}{l}\text { Not } \\
\text { done }\end{array}$ & $\begin{array}{l}\text { Not } \\
\text { done }\end{array}$ & $\begin{array}{l}\text { Not } \\
\text { done }\end{array}$ & \\
\hline 3 & Relapse, 6-mercaptopurine & 5.7 & 4.1 & 24 & 2500 & 2.56 & 44 & 13 & 48 & 4.11 \\
\hline 4 & Relapse, 6-mercaptopurine & 9.8 & 3.8 & 48 & 3000 & 9.02 & 58 & 36 & 48 & 2.27 \\
\hline 5 & Relapse, 6-mercaptopurine & 9.1 & 5.6 & 24 & 3000 & 5.04 & 42 & 21 & 48 & 2.64 \\
\hline 6 & Relapse, 6-mercaptopurine & 13.8 & 13.0 & 24 & 2500 & 0.73 & IS $\S$ & IS\$ & IS\$ & \\
\hline 7 & Diagnosis & 8.9 & 8.3 & 48 & 3000 & 0.75 & 46 & 30 & 48 & 1.98 \\
\hline
\end{tabular}

* Total cells counted for each time period.

$\ddagger[Z]=$ absolute $Z$ value.

$\S \mathrm{IS}=$ inadequate sample. 


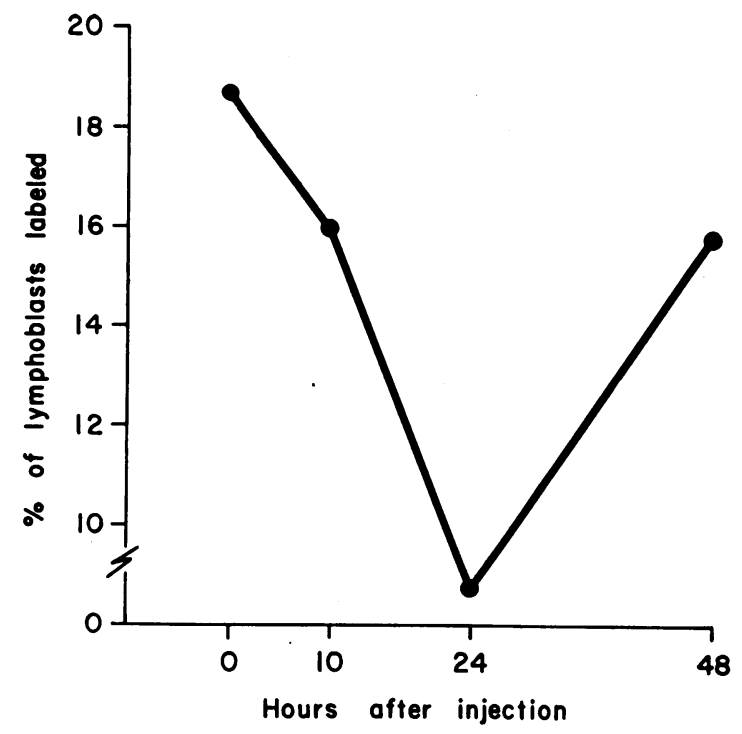

Figure 5 Representative example of time course of effect of hydrocortisone. Acute lymphoblastic leukemia.

cortisone injection. The minimal labeling index and minimal number of mitotic figures after therapy are shown in Table III. In five of seven patients the labeling index at the nadir was significantly decreased from pretreatment levels. In four of these five patients the nadir occurred at $24 \mathrm{hr}$, and there was a subsequent significant increase at $48 \mathrm{hr}$. In patient No. 4 the nadir occurred at $48 \mathrm{hr}$.

The time course for response in patient No. 1 in Table III is shown in Fig. 5. The maximal decrease in labeling index occurred at $24 \mathrm{hr}$ with a rebound observed at $48 \mathrm{hr}$.

No decrease in quantity of label in labeled cells as indicated by mean grain count was found in two patients in whom this determination was done, as shown in Table II. In the patients in whom there was a decrease in labeling index and in whom mitotic figures were counted, there was a decrease in number of mitotic figures 48 $\mathrm{hr}$ after the injection. In patient No. 7 in whom there was no change in labeling index, a decrease in number of mitotic figures was observed at $48 \mathrm{hr}$.

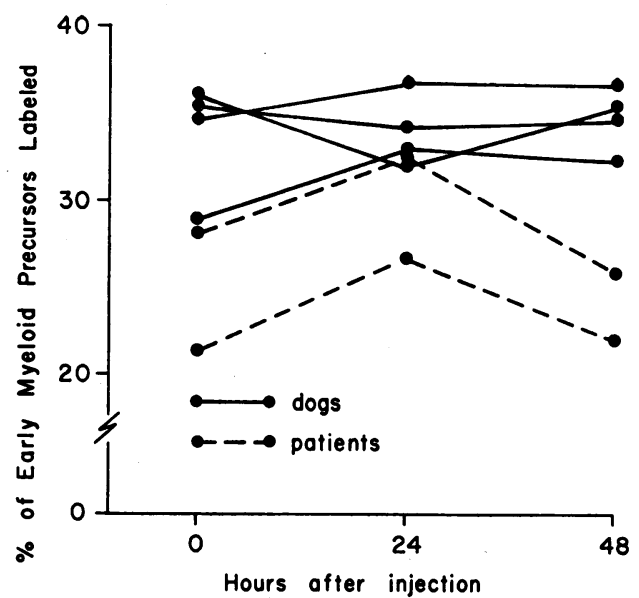

Figure 6 Effect of hydrocortisone on nonleukemic marrows.

The changes in volume of marrow buffy coat are shown in Table IV. In all of the responsive patients there was a striking decrease in the volume of marrow buffy coat $24 \mathrm{hr}$ after injection. In the three responsive patients in whom marrow samples were obtained $1 \mathrm{hr}$ after the injection, a decrease in marrow buffy coat was already found at that time. In patient Nos. 6 and 7 there was no change in marrow buffy coat.

Acute myeloblastic leukemia and nonleukemic marrows. Two children with acute myeloblastic leukemia were studied at the time of diagnosis. A single injection of hydrocortisone in a dose of $11 \mathrm{mg} / \mathrm{kg}$ body weight was given. No decrease in per cent of labeled cells occurred. In fact in both patients a slight but significant increase in per cent of labeled cells was observed at 24 or $48 \mathrm{hr}$. The changes in number of mitotic figures were not consistent in the two patients. In one a slight but significant decrease occurred at $24 \mathrm{hr}$, and in the other a slight but significant increase was observed at the same time period. There was no change in the quantity of marrow buffy coat in either patient.

The effect of a single injection of hydrocortisone in a dose of $11 \mathrm{mg} / \mathrm{kg}$ body weight on nonleukemic myeloid precursors in a patient with idiopathic thrombocytopenic purpura, a patient with congenital hypoplastic

TABLE IV

Quantity of Buffy Coat of Marrow before and after Hydrocortisone Therapy: Acute Lymphoblastic Leukemia

\begin{tabular}{|c|c|c|c|c|c|c|c|c|}
\hline $\begin{array}{c}\text { Hours after } \\
\text { injection }\end{array}$ & Patient No...... & 1 & 2 & 3 & 4 & 5 & 6 & 7 \\
\hline 0 & & 14.8 & 30.0 & 13.8 & 25.0 & 4.0 & 2.2 & .5 \\
\hline 1 & & & 10.0 & 9.5 & 1.0 & & 2.0 & 1.0 \\
\hline 6 & & & 2.5 & & & 1.0 & & \\
\hline 10 & & 15.5 & & & & & & \\
\hline 24 & & 4.0 & 1.0 & 7.5 & 2.5 & 1.5 & 2.5 & .8 \\
\hline 48 & & 4.0 & 15.0 & 2.8 & 0.5 & 15.0 & 2.0 & 1.9 \\
\hline
\end{tabular}


anemia, and four normal dogs is shown in Fig. 6. There was no change in the per cent of labeled myeloid precursors in any of these studies. The effect on the number of mitotic figures was determined in two of the dogs. The results were not consistent in these two studies with one dog having no change and the other having a slight but significant decrease at $24 \mathrm{hr}$. The volume of marrow buffy coat was measured in one of the children and in two of the dogs. No changes were found.

\section{DISCUSSION}

In this study the effect of three chemotherapeutic agents on the leukemic cells of the bone marrow in patients with acute leukemia was assessed. The techniques used have been previously established as reflecting the proliferative capacity of marrow leukemic cells, and the marrow sites sampled have been shown to be representative of the marrow population as a whole (6-9).

Vincristine has been demonstrated to cause metaphase arrest in dividing cell populations (10). This effect of vincristine on lymphoblasts in vivo was confirmed in this study. After a lag period of $24 \mathrm{hr}$ after the maximal increase in number of mitotic figures, a decrease in labeling index was also observed. The time relationship between the two effects indicates that as vincristine arrests cells in mitosis, it removes these from the mitotic cycle and subsequent deoxyribonucleic acid (DNA) synthesis. The delayed effect on the buffy coat indicates that this change was secondary to the effect of the drug on cells in the mitotic cycle, rather than a primary cytotoxic or lytic effect.

Cytosine arabinoside has been shown to inhibit DNA synthesis in cells in tissue culture (11). The marked decrease in incorporation of tritiated thymidine in lymphoblasts within $4 \mathrm{hr}$ after injection of cytosine arabinoside indicates that the primary in vivo effect of this drug on lymphoblasts is likewise inhibition of DNA synthesis. The return in the labeling index to pretreatment levels before a return of the number of mitotic figures toward pretreatment levels in all four studies confirms this effect. The decrease in number of cells in mitosis was secondary to decreased DNA synthesis activity.

Synchronization of the mitotic cycle in HeLa cells has been reported after inhibition of their reproduction by cytosine arabinoside (12). A similar in vivo effect of the drug in these studies is suggested by the marked increase in labeling $48 \mathrm{hr}$ after injection of cytosine arabinoside on two occasions in the one patient and a significant increase observed in a second patient. The lack of decrease in volume of marrow buffy coat indicates that with this dose of the drug cells were not immediately killed.
Involution of lymphoid tissue in mice induced by corticosteroid administration has been shown to result by means of three mechanisms: lysis of cells (13), inhibition of DNA synthesis (14), and inhibition of mitosis $(13,15)$. The studies reported here indicate that the same three mechanisms are operative in the effect of corticosteroids on the leukemic cell population of children with acute lymphoblastic leukemia.

The $24 \mathrm{hr}$ lag period between the nadir of the labeling index and the subsequent nadir of the number of mitotic figures after an injection of hydrocortisone is consistent with the decrease in number of mitotic figures being secondary to inhibition of DNA synthesis. The 24 hr lag period after hydrocortisone injection before the nadir of labeling index indicates that the observed inhibition of DNA synthesis at that time was caused by a decreased entry of cells into the DNA synthesis phase. The finding that the effect of hydrocortisone was to decrease the per cent of labeled cells but not the quantities of label per labeled cell supports this explanation.

Lysis of mouse leukemia cells by corticosteroids has been demonstrated by Dougherty and White (13). The same effect in human leukemia has been suggested by the increased uric acid excretion after administration of the drug (16). The marked effect of hydrocortisone on the volume of marrow buffy coat in the children with acute lymphoblastic leukemia in this study is in keeping with these previous observations.

As might be expected from the clinical response of patients with acute myeloblastic leukemia, no such striking effect of corticosteroids was seen on the per cent of cells labeled with tritiated thymidine or volume of marow buffy coats in the two patients with that form of leukemia. A similar lack of effect of hydrocortisone on early myeloid precursors and marrow buffy coats in human and canine nonleukemic marrow populations was seen.

These studies demonstrated that the passage of cells through the sequential stages of the mitotic cycle is interdependent, and a block or slowing down of cell movement through any one of these is reflected by subsequent changes in the other phases as well. Thus simultaneous administration of two or more drugs whose primary effects are on the mitotic cycle could limit their effectiveness. For example conceivably it would not be of value to simultaneously administer drugs such as cytosine arabinoside which inhibits DNA synthesis and vincristine which arrests cells in mitosis. Simultaneous administration might result in inhibition of DNA synthesis by the cytosine arabinoside with the resultant limitation of cells entering mitosis reducing the effectiveness of the vincristine.

It therefore appears that knowledge of the effects of chemotherapeutic agents on the mitotic cycle and of the 
time course of these effects is essential for proper choice and timing of drug therapy. Furthermore, if advantage could be taken of the partial synchronization of the mitotic cycle in the leukemic cell population achieved by cytosine arabinoside to give another mitotic cycledependent drug later at the appropriate phase of the cycle, perhaps a greater therapeutic effect could be achieved.

\section{ACKNOWLEDGMENTS}

The authors thank The Upjohn Co., Kalamazoo, Mich., for supplying cytosine arabinoside. We acknowledge the technical assistance of Virginia Fisher, Carol Whidden, Ann Damon, and Clare Anderson. We thank Miss Betty Powell for typing the manuscript.

This investigation was supported by grants from the U. S. Public Health Service (CA 04826 and FR 00123).

\section{REFERENCES}

1. Boggs, D. R., M. M. Wintrobe, and G. E. Cartwright. 1962. The acute leukemias. Analysis of 322 cases and review of the literature. Medicine. 41: 163.

2. Hayhoe, F. G. J., D. Quaglino, and R. Doll. 1964. The cytology and cytochemistry of acute leukaemias; a study of 140 cases. In Special Report Series, No. 304. Medical Research Council, Her Majesty's Stationery Office, London. 1.

3. Japa, J. 1942. A study of the mitotic activity of normal and human bone marrow. Brit. J. Exp. Pathol. 23: 272.

4. Sturgeon, P. 1951. Volumetric and microscopic pattern of bone marrow in normal infants and children. I. Volumetric pattern. Pediatrics. 7: 577.

5. Dixon, W. J., and F. J. Massey. 1951. Introduction to statistical analysis. McGraw-Hill Book Company, New York. 104.
6. Mauer, A. M., and V. Fisher. 1962. Comparison of the proliferative capacity of acute leukaemia cells in bone marrow and blood. Nature (London). 193: 1085.

7. Rubini, J. R., S. Keller, and E. P. Cronkite. 1965. In vitro DNA labeling of bone marrow and leukemic blood leukocytes with tritiated thymidine. I. Physical and chemical factors which affect autoradiographic cell labeling. J. Lab. Clin. Med. 66: 483.

8. Saunders, E. F., B. C. Lampkin, and A. M. Mauer. 1967. Variation of proliferative activity in leukemic cell populations of patients with acute leukemia. J. Clin. Invest. 46: 1356.

9. Mauer, A. M., and V. Fisher. 1966. Characteristics of cell proliferation in four patients with untreated acute leukemia. Blood. 28: 428.

10. Frei, E., III, J. Whang, R. B. Scoggins, E. J. Van Scott, D. P. Rall, and M. Ben. 1964. The stathmokinetic effect of vincristine. Cancer Res. 24: 1918.

11. Brehaut, L. A., and P. H. Fitzgerald. 1968. The effects of cytosine arabinoside on the cell cycle of cultured human leucocytes: a microdensitometric and autoradiographic study. Cell Tissue Kinet. 1: 147.

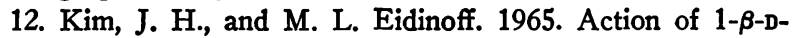
arabinofuranosylcytosine in the nucleic acid metabolism and viability of HeLa cells. Cancer Res. 25: 698.

13. Dougherty, T. F., and A. White. 1945. Functional alterations in lymphoid tissue induced by adrenal cortical secretion. Amer. J. Anat. $77: 81$.

14. Stevens, W., C. Colessides, and T. F. Dougherty. 1965. Effects of cortisol on the incorporation of thymidine$2-{ }^{14} \mathrm{C}$ into nucleic acids of lymphatic tissue from adrenalectomized CBA mice. Endocrinology. 76: 1100.

15. Nowell, P. C. 1961. Inhibition of human leukocyte mitosis by prednisolone in vitro. Cancer Res. 21: 1518.

16. Sandberg, A. A., G. E. Cartwright, and M. M. Wintrobe. 1956. Studies on leukemia. I. Uric acid excretion. Blood. 11: 154 . 